\title{
Keterlibatan Amerika Serikat dalam Perang Vietnam: Faktor Ideologi, Identitas, dan Idealisme
}

\author{
Demas Nauvarian \\ Universitas Airlangga
}

\begin{abstract}
ABSTRAK
Tulisan ini bertujuan untuk memverifikasi justifikasi demokrasi Amerika Serikat dalam konsistensinya di Perang Vietnam selama dua dekade (1955-1975). Hal ini dilakukan dengan metode analisis konten terhadap dokumen-dokumen kebijakan luar negeri Departemen Pertahanan Amerika Serikat di Vietnam-the Pentagon Papers-yang merupakan dokumen primer yang mencatat proses pembuatan kebijakan luar negeri Amerika Serikat selama Perang Vietnam. Hal ini kemudian dicocokkan dengan pandangan Teori Perdamaian Demokratis (Democratic Peace Theory) yang selama ini banyak diargumenkan sebagai dasar pengambilan kebijakan dalam berbagai perang proksi di era Perang Dingin. Tulisan ini berkesimpulan bahwa terdapat berbagai konsiderasi lain, baik berupa faktor rasional maupun irrasional, yang digunakan Amerika Serikat dalam Perang Vietnam.
\end{abstract}

Kata-kata kunci: Perang Vietnam, Amerika Serikat, Teori Perdamaian Demokratis, Pentagon Papers, kebijakan perang

This paper aims to prove the justification of US democracy in its consistency in the Vietnam War for two decades (1955-1975). This was done using the content analysis method of the US Department of Defense's foreign policy documents in Vietnam - the Pentagon Papers - which were the primary documents related to the process of making US foreign policy during the Vietnam War. This was later matched with the view of Democratic Peace Theory (Democratic Peace Theory) which has been widely argued as the basis for policy making in the proxy war in the Cold War era. This paper concludes that there are various other considerations, both rational and irrational factors, which were used by the United States in the Vietnam War.

Keywords: Vietnam War, United States, Democratic Peace Theory, Pentagon Papers, war policy 
Keterlibatan dan intervensi Amerika Serikat dalam berbagai urusan domestik negara-negara di berbagai belahan dunia pada dekade 1950 hingga 1970an merupakan salah satu pembahasan yang dominan dalam studi Perang Dingin. Politik luar negeri Amerika Serikat pasca-Perang Dunia II ditandai dengan adanya ketegangan dengan Uni Soviet selaku mantan aliansi yang telah dimulai pada beberapa konferensi perang dan pasca-perang seperti Konferensi Casablanca, Konferensi Tehran, Konferensi Yalta, dan Konferensi Postdam, yang memuncak dengan kegagalan terbentuknya kesepahaman atas visi terhadap wilayah Jerman pasca-perang secara khusus, dan peta geopolitik dunia baru pada umumnya (Swift 2003). Ketegangan ini disalurkan melalui upaya kedua adidaya dalam menanamkan pengaruhnya diseluruh dunia, memasuki masa yang dikenal sebagai Perang Dingin.

Berbagai hipotesis kemudian menilai bahwa gesekan langsung antara kedua kekuatan raksasa tersebut mampu memicu timbulnya Perang Dunia III yang berskala lebih besar dibanding dua perang sebelumnya. Hal ini dieskalasi dengan adanya proxy war-metode perang dengan menggunakan aktor boneka dalam mencapai kepentingan di suatu wilayah- yang kemudian menjadi sebuah metode yang kemudian tampak sangat prominen pada era ini. Wallerstein (2001 dalam Tsuitsui 2004) memetakan bahwa terdapat beberapa fenomena perpecahan yang cukup besar dalam era ini, diantaranya adalah Perang Korea, Perpecahan Jerman, Revolusi China, dan Perang Vietnam. Dari empat fenomena besar di atas, dua di antara-nya-Korea dan China-masih mengalami perpecahan yang berlangsung hingga sekarang. Namun di sisi lain, baik Jerman maupun Vietnam masih meninggalkan legasi puing-puing Perang Dingin yang bersifat tunggal. Perbedaannya, Unifikasi Jerman menghasilkan negara kesatuan federasi Jerman yang berasaskan liberalismedemokrasi. Sementara kejatuhan Vietnam Selatan yang didukung Amerika Serikat terhadap Pemerintah Komunis Vietnam Utara menghasilkan rezim sayap kiri yang dapat kita lihat hingga saat ini (Hass 1984 dalam Kim 2009).

Perang Vietnam merupakan sebuah fenomena yang unik ketika dilihat dalam perspektif politik pembendungan Amerika Serikat. Kekalahan bukanlah sesuatu yang sering diterima oleh Amerika Serikat. Hal ini ditunjukkan oleh adanya konsistensi dukungan politik dan militer Amerika Serikat terhadap Vietnam Selatan selama lima masa kepresidenan-sejak Presiden Truman hingga Presiden Nixon-meski pada tahun 1960-an, pada era Presiden Kennedy, 
studi yang dilakukan Menteri Luar Negeri Amerika Serikat Robert McNamara menunjukkan bahwa Amerika Serikat mengalami kekalahan konstan yang tidak memberikan keuntungan bagi Amerika Serikat sama sekali, atau paling tidak, "bukan keuntungan yang dapat dirasakan secara langsung ataupun cepat oleh Bangsa Amerika" (Departemen Pertahanan AS 1971d). Akan tetapi, fakta ini secara utuh ditutupi oleh pemerintah AS dari masa ke masa, membuat adanya gelombang protes besar-besaran pada tahun 1972 pada era Presiden Nixon. Tulisan ini bertujuan untuk menganalisis konsistensi kebijakan luar negeri AS dalam mempertahankan dukungan politik dan militer terhadap Vietnam Selatan dalam Perang Vietnam dari masa ke masa melalui level analisis identitas nasional, khususnya dalam statusnya sebagai global great power dan democracy promotor dalam sistem internasional Perang Dingin.

\section{Demokrasi Prasyarat Perdamaian: Pilar Domestik Konstitusional Perdamaian Liberal}

Demokrasi merupakan salah satu konsep yang tak terpisahkan dari pemikiran politik barat, dan merupakan salah satu turunan dari tradisi berpikir Liberalisme yang mulai berkembang di Eropa Barat dan Amerika Utara pada abad ke-18. Salah satu pemikiran yang mendasari tidak hanya aliran Liberalisme, namun juga ambivalensi perdamaian dan demokrasi, adalah Perpetual Peace yang ditulis oleh Immanuel Kant pada 1795 (dalam Doyle 2005). Argumen mendasar yang diajukan Kant adalah mengenai prasyaratprasyarat liberal dalam penciptaan perdamaian dunia, yang Kant kemudian kelompokkan dalam tiga sumber utama, yaitu sumber konstitusional, internasional, dan kosmopolitan. Doyle (2005) berargumen bahwa ketiga sumber tersebut menjadi tiga pilar penting dari apa yang kemudian disebut sebagai perdamaian ala liberal. Kant (1970 dalam Doyle 2005) kemudian berargumen bahwa demokrasi merupakan elemen utama dari sumber konstitusional perdamaian liberal. Dalam pandangan Liberalisme, demokrasi merupakan sebuah cara dalam memenuhi hasrat dan kebutuhan hidup individu dalam masyarakat melalui proses dalam sistem politik. Hal ini dilakukan dengan menciptakan keadilan dalam distribusi sumber daya dalam memenuhi kebutuhan individu-sesuatu yang menurut kaum liberalis mampu menekan potensi konflik dan perang.

Pugh (2005) kemudian merangkum setidaknya empat faktor dalam penciptaan perdamaian internasional melalui demokrasi. Faktor 
pertama dan kedua sangatlah berkaitan, yaitu faktor pemimpin dan publik. Sebagai entitas yang rasional, publik akan cenderung menghindari perang dalam menjaga kesejahteraan dan kepemilikan sumber dayanya. Hal ini kemudian tersalurkan melalui demokrasi dan direfleksikan oleh pemimpin. Hal ini membawa kita pada faktor ketiga, yaitu kekayaan nasional, yang berarti sebagai sebuah entitas rasional, negara juga akan mencerminkan keinginan rakyatnya dalam melindungi sumber daya yang dimilikinya. Faktor keempat adalah sistem pemerintahan dan pembuatan kebijakan mengenai pemisahan dan penyeimbangan kekuasaan, serta mencegah adanya tindakan-tindakan individu yang irrasional sebagaimana dapat terlihat dalam rezim-rezim otoritarian ${ }^{1}$. Hal ini adalah apa yang dipercayai Kant (dalam Rosato 2003) sebagai sebuah mekanisme dalam bentuk pemerintahan republik. Kant berargumen bahwa republikanisme merupakan jalan menuju sebuah perdamaian abadi yang diciptakan dan ditujukan bagi umar manusia. Maka kemudian, dapat dilihat bahwa hubungan demokrasi dan perdamaian memang diciptakan dalam konteks liberal.

\section{Demokratisasi atau Intervensi? Perang Proksi dalam Perang Dingin}

Demokrasi yang telah menjadi norma panutan internasional tidak lepas dari peran promotornya yang merangkap sebagai hegemon global sejak berakhirnya Perang Dunia II pada 1945. Amerika Serikat, dalam pandangan Teori Long-Cycle yang dikemukakan oleh Modelski (1957), telah menggantikan posisi Inggris sebagai hegemon sistem internasional, dan oleh karena itu, mendapat keuntungan dalam menciptakan tatanan dunia sesuai dengan visinyavisi perdamaian demokratis liberal. Maka kemudian dalam menciptakan tatanan global yang sesuai dengan visi tersebut, dapat diamati bahwa kemudian Amerika Serikat melakukan serangkaian intervensi militer dengan justifikasi sebagai "upaya menyebarkan dan mengaplikasikan demokrasi"-sebuah proses yang kemudian

\footnotetext{
1. Dalam rezim-rezim otoritarian, kontrol politik seringkali dipegang baik oleh satu individu (monarki), maupun sekelompok individu (otokrasi). Hal ini kemudian memungkinkan adanya faktor-faktor sosio-psikologis serta biologis dalam menciptakan perang, sebab pembuatan kebijakan perang tidak mengalami proses rasionalisasi. Salah satu contoh adalah Perang Sipil Suriah yang tengah terjadi sejak 2011, dan berbagai analisis menunjukan dominasi peran Presiden Suriah Bashar AlAssad dalam kontinuitas perang sipil ini (Zisser, 2018). Kant (1970, dalam Doyle, 2005) menyebut perbandingan ini sebagai "Republican caultion and hesitation, in place of autoratic caprice".
} 
dikenal sebagai demokratisasi. Namun kemudian, sebagaimana diargumenkan oleh Dockrill dan Hopkins (2006), intervensi yang disamarkan sebagai perang demokratisasi ini sering kali juga memiliki status sebagai perang proksi-sebuah metode perang diantara dua pihak atau lebih yang tidak secara langsung terlibat dalam kontak militer fisik, melainkan menggunakan pihak ketiga dan seterusnya sebagai perpanjangan tangan.

Dalam hal ini, perang proksi sebagaimana digarisbawahi oleh Swift (2003), merupakan salah satu fitur penting dari era Perang Dinginsebuah periode dalam sejarah dunia yang didominasi oleh adanya tensi politik tinggi diantara dua adidaya yang berkuasa pada era tersebut, Amerika Serikat dan Uni Soviet. Perang proksi merupakan sebuah metode yang, bagi aktor utamanya, bersifat murah dan rendah resiko. Karl Deutsch (1964 dalam Mumford 2013) mendefinisikan perang proksi sebagai "konflik internasional diantara dua kekuatan asing, diperjuangkan dalam wilayah negara ketiga, dan menggunakan sumber daya negara tersebut, dalam mencapai strategi dan tujuan internasional". Maka kemudian, sebagaimana diargumenkan Mumford (2013), perang proksi akan selalu menjadi manifestasi intervensi satu negara terhadap negara lain. Dalam hal ini, berbagai perang proksi yang dilakukan oleh Amerika Serikat pada Perang Dingin-salah satunya Perang Vietnam-selalu dijustifikasi sebagai sebuah upaya dalam menanamkan demokrasi ke negara non-demokratis.

Proses dekolonialisasi pasca Perang Dunia II yang berlangsung setelah berkembangnya ide-ide mengenai self-determination di negara-negara barat ternyata bukan menjadi akhir dari intervensi asing dan konflik di Asia Tenggara. Alih-alih, Asia Tenggara menjadi tempat berlabuh kembalinya berbagai kepentingan negara-negara barat di wilayah global south, khususnya dalam membawa agenda imperialisme. Dalam hal ini, Hack dan Wade (2009) menjelaskan bahwa gelombang liberalisme dan demokrasi yang masuk ke wilayah Asia Tenggara kemudian mengalami benturan dengan spektrum politik sayap kiri berupa gerakan-gerakan komunisme yang menyebar baik dari Uni Soviet maupun Tiongkok, serta gerakangerakan nasionalis anti-neokolonialisme yang berkembang di wilayah ini. Secara umum, kawasan Asia-Pasifik sendiri mengalami adanya pergeseran konstelasi geopolitik.

Kontestasi ideologi sebagai konflik utama dalam Perang Dingin sendiri berkembang pesat di Asia Tenggara. Westad (2005 dalam Wade 2009) menjelaskan bahwa great power rivalry merupakan 
elemen kunci dari politik Perang Dingin yang diaplikasikan melalui perebutan pengaruh di berbagai wilayah dunia ketiga. Westad (2005 dalam Wade 2009) menyebut hal ini sebagai sebuah kolonialisme "with a slightly different means". Weatherbee (2009) secara umum mendefinisikan Perang Dingin di Asia Tenggara sebagai sebuah perpanjangan tangan dari politik pembendungan komunisme yang dilakukan oleh Amerika Serikat. Maka kemudian, tidak dapat dihindarkan bahwa trajektori Perang Dingin di Asia Tenggara menarik perhatian Amerika Serikat ketika komunisme mulai berkembang di wilayah ini. Dalam hal ini, kepentingan utama Amerika Serikat di Asia Tenggara dipicu oleh adanya konsep teori Domino-sebuah interrelasi strategis yang bersifat ideologis yang bertesis bahwa jatuhnya suatu negara kedalam jurang komunisme akan menciptakan spillover yang merambat ke negara-negara di sekitarnya. Sebagaimana dijelaskan oleh Min Shu (2017), teori domino menyatakan bahwa kekalahan di satu negara terhadap komunisme sama dengan kekalahan di satu wilayah. Teori domino inilah yang menjadi dasar politik pembendungan Amerika Serikat tidak hanya di Asia Tenggara, tetapi juga berbagai wilayah dunia ketiga lainnya (Hack \& Wade 2009).

Hal ini terbukti ketika kultivasi komunisme di Asia Tenggara mulai muncul, ditandai dengan munculnya berbagai gerakan insurjensi komunis dalam upaya menggulingkan rezim demokratis di beberapa negara seperti Indonesia, Burma, Filipina, dan Malaysia (Turnbull 2009 \& Weatherbee 2009). Amerika Serikat menekankan pentingnya 'keamanan bersama' dalam statusnya sebagai hegemon dan polisi dunia dalam Perang Dingin, menjustifikasi berbagai intervensinya di Asia Tenggara sebagai upaya dalam menciptakan wilayah Asia Tenggara yang 'bebas, independen, dan demokratis'. Namun, sebagaimana dinyatakan oleh Weatherbee (2009), intervensi Amerika Serikat di negara-negara Asia Tenggara tidak datang tanpa efek samping. Beberapa negara seperti Indonesia dan Burma kemudian justru melakukan reaksi independen dan penolakan terhadap intervensi Amerika Serikat di Asia Tenggara. Sebagai contoh, intervensi Amerika Serikat di Asia Tenggara dan Indonesia justru memicu kedekatan Presiden Soekarno untuk mendekatkan diri ke Tiongkok dan Korea Utara dengan membentuk poros Jakarta-Peking-Pyongyang (Weatherbee 2009).

Sebagaimana dijelaskan Ang Cheng Guan (2013), Perang Vietnam merupakan salah satu upaya Amerika Serikat untuk mengulangi dan memperbaiki pride yang dimilikinya di Asia Tenggara. Turnbull 
(2008) menambahkan bahwa pola Amerika Serikat dalam melakukan pembendungan terhadap negara-negara komunis merupakan overreaction atas aksi-aksi pemerintah-pemerintah komunis seperti Korea Utara dan Vietnam yang digunakannya sebagai justifikasi. Chua (2001) juga menambahkan bahwa gerakan-gerakan komunis yang muncul di Asia Tenggara umumnya merupakan hasil perpanjangan tangan dari rezim Kuomintang Tiongkok, dan bahwa sesungguhnya Uni Soviet tidak memerankan peranan yang lebih dominan dibanding Tiongkok di Asia Tenggara. Kompetisi politik pembendungan ini tidak terjadi hanya sebatas terhadap komunisme, tetapi bahkan terhadap gerakan-gerakan nasionalis, yang dilakukan Amerika Serikat dalam menanamkan pengaruhnya di wilayah Asia Tenggara (Turnbull 2008).

Maka kemudian, dapat dianalisis bahwa sebagaimana dinyatakan oleh Mansfield dan Snyder (1995), tesis-tesis yang dikemukakan oleh teori perdamaian demokratis menjadi motivasi utama bagi Amerika Serikat dalam melaksanakan intervensi dan demokratisasi ke berbagai wilayah dunia dalam rangka membendung efek domino komunisme. Dalam pandangan teori perdamaian demokratis, diperlukan adanya persebaran demokrasi dalam menciptakan perdamaian liberal. Hal ini, menurut Doyle (2005) berkaitan dengan pilar internasionalisme dari perdamaian liberal. Namun kemudian, Mansfield dan Snyder (1995) juga menyatakan kelemahan dari perang demokratisasi. Proses transisi demokrasi seringkali bersifat konfliktual. Hal ini disebabkan karena terdapat ketidaksesuaian diantara nilai-nilai demokrasi, khususnya demokrasi liberal, dengan nilai-nilai status quo yang diterapkan di suatu negara. Von Hippel (2004) kemudian menyimpulkan bahwa terlepas dari adanya visi baik Amerika Serikat dalam membangun tatanan global demokratis, karateristik non-komitmen terhadap prinsip non-intervensi sebagai salah satu norma global menjadi ciri utama intervensi Amerika Serikat dalam era Perang Dingin.

Dalam hal ini, Turnbull (2008) mengungkapkan bahwa terdapat dua fase gelombang demokratisasi. Pertama, yaitu pada akhir Perang Dunia II yang ditandai dengan adanya dekolonialisasi negaranegara dunia ketiga. Kedua, yaitu pada akhir Perang Dingin, tepatnya dalam kemenangan liberalisme atas sosialisme ditandai dengan adanya demokratisasi di berbagai wilayah dunia. Namun kemudian, perlu dicatat bahwa permasalahan-permasalahan demokratisasi ini muncul apabila proses tersebut berjalan lancar. Semantara itu, seperti argumen penulis di awal, Perang Vietnam merupakan salah 
satu bentuk kegagalan dan manifestasi kritik terhadap teori perdamaian demokratis. Selain itu, meskipun kemudian teori ini digunakan sebagai landasan dari kebijakan Perang Vietnam Amerika Serikat (bersama dengan kebijakan pembendungan), faktor identitas dan idealisme liberal yang diperburuk oleh mispersepsi merupakan faktor utama dari konsistensi Amerika Serikat dalam Perang Vietnam.

\section{Memikirkan Kembali Nilai "Demokrasi" dalam Teori Perdamaian Demokratis}

Dalam pandangan kaum realis, sistem internasional yang anarki dan berfokus pada peningkatan kekuatan nasional menjadikan adanya intervensi-intervensi militer sebagai sebuah mekanisme normal untuk mencapai keamanan dalam politik global. Namun, teori perdamaian demokratis bukanlah turunan dari pandangan realis, melainkan antitesisnya yakni Liberalisme. Dalam pandangan induk demokrasi ini, Liberalisme menakankan pada pentingnya hukum internasional dan organisasi internasional yang terkonstruksi dalam sistem negara Westphalia yang anarki. Instrumen-instrumen liberal di atas digunakan untuk mengatur perilaku negara-negara dalam bersikap dan menciptakan tatanan dalam sistem internasional. Dalam hal ini, perlu dipahami bahwa sebenarnya nilai-nilai inti Liberalisme tidak menyarankan adanya penggunaan kekerasaan, paksaan, maupun pelanggaran terhadap instrumen-instrumen tatanan internasional demi mengaplikasikan demokrasi dalam suatu negara. Namun demikian, hal-hal tersebut justru dilakukan sebagai upaya promosi demokrasi.

Lebih lanjut, Mansfield dan Snyder (1995) menjelaskan bahwa aksi intervensi dalam rangka demokratisasi justru menimbulkan adanya instabilitas dalam tingkat regional dan global. Demokratisasi seharusnya dilakukan dalam kerangka demokratis. Selain itu, Brock (2006) juga membantah adanya justifikasi dari "semangat kosmopolitanisme Kantian" sebagai pembenaran terhadap intervensi-intervensi tersebut. Rengger (2006) berargumen bahwa intervensi-intervensi yang didasarkan pada teori perang demokratis (democratization war theory) ini sesungguhnya tidak memiliki justifikasi moral terhadap berbagai pihak, dan berlawanan dengan adanya orientasi moral individualistis Liberalisme. Sejalan dengan argumen tersebut, Rosato (2003) berargumen bahwa intervensi-intervensi Amerika Serikat dalam negara- 
negara non-demokratis itu sendiri lebih sering mengabaikan adanya hasil demokratis. Alih-alih, Amerika Serikat justru "memusuhi demokrasi dengan memasang berbagai rezim otokratis namun antikomunis dalam kerangka politik pembendungan. Selain itu, Rosato (2003) juga berargumen bahwa Amerika Serikat tidak memiliki indikator yang jelas dalam menentukan dan mempersepsikan demokrasi di negara-negara lain. Hal ini dibuktikan dengan adanya perpecahan dalam internal Amerika Serikat terkait dengan status demokrasi negara-negara asing.

\section{Tabel 1. Intervensi-Intervensi Antidemokratik Amerika Serikat pada Perang Dingin}

\begin{tabular}{|c|c|}
\hline Target & Description \\
\hline Iran (1953) & $\begin{array}{l}\text { Mossadeq's foreign policy aimed at disengagement from superpower rivalry. Domestically, } \\
\text { allied with or suppressed communists as necessary. United States assisted coup that } \\
\text { overthrew him. }\end{array}$ \\
\hline Guatemala (1954) & $\begin{array}{l}\text { Four communists in government and hardly any in general population. Army, the key } \\
\text { institution in politics, was anticommunist. Arbentz undertook a number of leftist reform } \\
\text { programs. United States financed and directed imvasion that replaced him. }\end{array}$ \\
\hline Indonesia (1957-) & $\begin{array}{l}\text { Sukarno's "guided democracy" only way simultaneously to democratize Indonesia and } \\
\text { prevent civil war. Communists performed well in } 1955 \text { elections. United States assisted } \\
\text { rebels seeking to oust Sukarno. }\end{array}$ \\
\hline British Guyana (1961-) & $\begin{array}{l}\text { Jagan consistently sought American support. Washington convinced he was leftist and } \\
\text { sponsored terrorist efforts to subvert him, then changed election laws to remove him. }\end{array}$ \\
\hline Brazil $(1961,1964)$ & $\begin{array}{l}\text { American role in Quadros's resignation (1961) unclear. Goulart's foreign policy neutral. At } \\
\text { home made no effort to legalize communist party or extend term illegally. Accepted East } \\
\text { European aid and undertook some leftist reforms. United States assisted in red scare } \\
\text { and coup that overthrew him. }\end{array}$ \\
\hline Chile (1973) & $\begin{array}{l}\text { Allende a socialist, but legislature controlled by center-right. United States approved } \\
\text { Chilean military coup that overthrew him. }\end{array}$ \\
\hline Nicaragua (1984-) & $\begin{array}{l}\text { Sandinistas were more democratic than American-backed Somoza dynasty. Held elections } \\
\text { in } 1984 \text { and bowed to international pressure in respecting a number of civil rights. United } \\
\text { States sought to roll back apparent communist threat. }\end{array}$ \\
\hline
\end{tabular}

Sumber: Rosato (2003, 590)

\section{Dua Dekade A.S. dalam Perang Vietnam: Demokrasi atau Mispersepsi?}

Perang Vietnam, atau dikenal juga dengan Perang Indochina kedua, adalah perang yang secara umum terjadi di Semenanjung Indochina-saat ini wilayah Vietnam, Laos, dan Kamboja-yang dimulai dengan adanya insurjensi dari kelompok pemberontak Vietnam Selatan terhadap Vietnam Utara pada 1 November 1955, dan diakhiri dengan kejatuhan Kota Saigon sebagai kota utama dalam kepemilikan Vietnam Selatan pada 30 April 1975 (Dockrill dan Hopkins 2006). Perang ini, sebagaimana diargumenkan oleh Mumford (2013), merupakan salah satu dari rangkaian perang proksi Perang Dingin, dan merupakan puncak dari Perang Dingin di Asia Tenggara. Perang Vietnam itu sendiri dapat dikatakan se- 
bagai Perang Indochina kedua karena merupakan kelanjutan dari Perang Indochina pertama yang terjadi pada tahun 1950-1954. Pada perang tersebut, Pemerintah Kolonial Perancis mendukung pemerintah Vietnam Selatam dalam upayanya untuk melakukan perlawanan terhadap pemberontak komunis Viet Minh yang berbasis di bagian utara Vietnam. Namun, hal ini gagal khususnya dikarenakan adanya insurgensi internal di pihak Vietnam Selatan dari National Liberation Front (NLF) Viet Cong yang didanai oleh pemerintahan Viet Minuh (Departemen Pertahanan AS 1971a). Pemberontak Viet Cong melakukan strategi perlawanan insurgensi gerilya terhadap pemerintah nasionalis Vietnam Selatan yang berlangsung hingga tahun 1959. Hal ini, sebagaimana dianalisis oleh Departemen Pertahanan AS (1971a), merupakan hasil dari kegagalan Konferensi Jenewa pada tahun 1954. Dalam hal ini, Amerika Serikat telah hadir di Indochina sejak Perang Indochina pertama, sebagai salah satu kekuatan yang mendukung presensi Perancis di Indochina dalam memberantas pemberontak Komunis melalui Military Assistance and Advisory Group (MAAG) Amerika Serikat, namun di saat yang sama juga mempromosikan kemerdekaan dan dekolonialisasi bagi Vietnam Selatan (Departemen Pertahanan AS 1971a).

\section{Rasionalitas dan Irrasionalitas AS memasuki Indochina}

Sebagaimana dikutip oleh Swift (2003), justifikasi yang diberikan oleh Pemerintahan Amerika Serikat, khususnya dalam pemerintahan Presiden Harry S. Truman dan Dwight Eisenhower adalah adanya perjuangan terhadap nilai-nilai demokrasi dan hak asasi manusia di Vietnam yang disinyalir mengalami kesengsaraan hebat akibat pengaruh Tiongkok. Namun, sebagaimana dikutip dalam The Pentagon Papers, keterlibatan Amerika Serikat pada awalnya merupakan sebuah bentuk dari komitmennya terhadap aliansi dan politik pembendungan, dan tidak menyebut adanya upaya perlindungan terhadap demokrasi di Vietnam (Departemen Pertahanan AS 1971a).

Politik Perang Dingin yang sangat bipolar mengharuskan Amerika Serikat untuk menjaga komitmen, citra, dan idealitasnya sebagai pemimpin blok liberal dalam sistem internasional. Departemen Pertahanan AS (1971a) menyebutkan bahwa intensi awal Amerika Serikat di Indochina bukanlah untuk mendukung Vietnam Selatan, melainkan untuk menjaga presensi Amerika Serikat di Asia Tenggara dan mencegahnya dari vacuum of power. Selain itu, keterlibatan Amerika Serikat di Indochina secara eksplisit juga dise- 
babkan oleh "adanya misinformasi dan miskalkulasi" (Departemen Pertahanan AS 1971a). Amerika Serikat mengakui bahwa terdapat mispersepsi mengenai seberapa jauh kekuatan dan peluang yang dimilikinya di Indochina, dan "menyadari dengan penyesalan di akhir" bahwa terlepas dari hasil dari perang di Indochina, keuntungan yang akan didapat dinilai lebih sedikit dibanding kerugiannya. Kedua hal diatas merupakan bentuk penjelas rasional perang-miskalkulasi (Fearon 1995) dan penjelas irrasional perang-mispersepsi (Jervis 1988).

\section{Irrasionalitas Konsistensi AS dalam Vietnam}

Terlepas dari rendahnya prospek kemenangan Amerika Serikat pada dekade 1950an yang disebabkan oleh dua faktor diatas, Amerika Serikat tercatat tetap konsisten dalam megirimkan pasukan untuk mendukung pasukan Vietnam Selatan. Konsistensi ini mulai muncul pada masa Presiden John F. Kennedy yang menjabat pasca Konferensi Jenewa. Konferensi Jenewa, sebagaimana dilaporkan oleh Departemen Pertahanan AS (1971b), merupakan sebuah kegagalan dan kerugian. Terlebih lagi, The Pentagon Papers kemudian melaporkan adanya "pengarahan informasi publik" dalam membentuk opini masyarakat dalam mendukung, atau setidaknya tidak menghalangi presensi Amerika Serikat di Vietnam. Departemen Pertahanan AS (1971b) melaporkan bahwa setidaknya hingga tahun 1964, terdapat sekitar dua puluh tiga ribu tentara Amerika Serikat di Vietnam, dan angka ini terus berlanjut mengikuti Insiden Teluk Tonkin pada tahun tersebut.

Departemen Pertahanan AS (1971b) melaporkan bahwa ketiadaan prospek kemenangan Amerika Serikat di Vietnam pada era pemerintahan Presiden Kennedy merupakan salah satu alasan dari upaya invasi Operasi Bay of Pigs pada awal 1960an. Akan tetapi, kegagalan Operasi Bay of Pigs justru menimbulkan efek yang lebih besar bagi Amerika Serikat secara umum, dan kebijakannya terhadap Vietnam secara khusus. Pertama, kegagalan operasi tersebut merupakan awal dari ketegangan dan stalemate nuklir selama tiga belas hari yang melibatkan Kuba dan Uni Soviet-sebuah krisis yang kemudian dikenal sebagai Krisis Misil Kuba (Swift 2003). Kedua, kekalahan Amerika Serikat justru semakin memukul kondisi Amerika Serikat dalam konstelasi politik Perang Dingin. Amerika Serikat belum mengalami satupun kemenangan mutlak sejak berakhirnya Perang Dunia II pada titik ini, dan Perang Vietnam merupakan satusatunya perang besar yang saat itu tengah dijalani. Hal inilah yang ditengarai oleh Lockhart (1993) sebagai alasan utama dari komitmen 
dan konsistensi keterlibatan Amerika Serikat dalam Perang Vietnam. Namun, sebagaimana dikutip oleh Departemen Pertahanan AS (1971d), intensifikasi kontribusi Amerika Serikat terhadap Vietnam Selatan mulai terjadi pada era pemerintahan Presiden Richard Nixon melalui serangkaian pertempuran udara di wilayah perbatasan kedua negara. Bahkan, terdapat narasi-narasi mengenai penggunaan senjata nuklir terhadap Vietnam Utara pada era Presiden Nixon (Departemen Pertahanan AS 1971c).

\section{Rasionalitas Keluarnya AS dan Berakhirnya Perang Vietnam: Efek Demokrasi}

Terdapat beberapa fenomena yang mendukung keluar atau berakhirnya kontribusi Amerika Serikat di Vietnam. Pertama, yaitu adalah insiden kebocoran Pentagon Papers yang menguak mengenai berbagai kebohongan pemerintah Amerika Serikat selama berbagai masa pemerintahan terkait potensi kemenangan Amerika Serikat di Indochina (Chaliand 1972). Kedua, yaitu adanya skandal Watergate yang menyangkut Presiden Nixon dan berimplikasi pada pengunduran dirinya, membuat timbulnya distrust terhadap pemerintah. Melemahnya opini publik terhadap pemerintah sekaligus kebijakan-kebijakan Indochina Amerika Serikat kemudian memaksa Presiden Gerald Ford untuk keluar dari arena pertempuran Perang Vietnam (Chaliand 1972). Dalam hal ini, penulis menganalisis bahwa hal ini merupakan salah satu contoh fenomena yang dikehendaki oleh Immanuel Kant (dalam Doyle 2005). Sebagai aktor yang rasional, masyarakat akan cenderung untuk menghindari perang dan menjaga perdamaian, dan demokrasi menjadi suatu alat bagi masyarakat dalam mengontrol kebijakan pemerintah untuk mengakhiri perang.

\section{Kesimpulan}

Teori perdamaian demokratis merupakan salah satu hasil pemikiran politik barat yang merupakan turunan dari Liberalisme. Liberalisme berkaca terhadap naluri manusia dalam memenuhi kebutuhannya, dan kemudian, terhindari dari konflik dan peperangan. Namun dalam mengevaluasi relevansi dan aplikasi dari teori ini, diperlukan adanya kacamata yang objektif dan bukan subjektif. Teori selalu hadir dalam konteks, dan sebagaimana dinyatakan oleh kaum pospositivis, tidaklah bebas nilai. Dalam hal ini, tulisan ini menyimpulkan bahwa teori perdamaian demokratis, sebagaimana teori-teori 
hasil pemikiran barat lainnya, merupakan refleksi dari tradisi masyarakat barat dan hanya memiliki kecocokan tinggi dalam wilayah tersebut.

Perang Vietnam, sebagaimana dikonklusikan oleh tulisan ini, merupakan sebuah upaya pembohongan masyarakat global dengan kedok demokratisasi, sementara melalui serangkaian analisis terhadap laporan kebijakan Amerika Serikat di Indochina Pentagon Papers, intensi ini tidak terlihat dalam proses pembuatan kebijakan Perang Vietnam. Alih-alih Amerika Serikat hadir di Indochina sebagai komitmennya terhadap politik pembendungan dan upaya menjaga aliansinya. Namun, dalam bingkai yang lebih besar, Amerika Serikat berusaha untuk mempertahankan idealismenya sebagai pemimpin blok liberal dalam Perang Dingin yang tidak sanggup lagi menerima kekalahan yang telah diterimanya di Perang Korea dan Krisis Misil Kuba. Selain itu, kehilangan presensi di Indochina, menurut Amerika Serikat, berarti kehilangan seluruh wilayah Asia Tenggara terhadap Tiongkok dan Uni Soviet dalam cengraman komunisme-sesuatu yang sangat berlawanan dengan nilai liberalismenya.

Dalam tulisan ini dapat dilihat bahwa demokrasi yang dipandang sebagai sistem pemerintahan yang baik, pada saat yang sama dapat menjadi sebuah instrumen yang mampu mengancam demokrasi itu sendiri, dan menimbulkan aksi-aksi non-demokratis sebagaimana terjadi di Vietnam. Namun pada akhirnya, demokrasi hadir sebagai upaya intelektual manusia dalam memenuhi kebutuhannya, dan menciptakan perdamaian. 


\section{Daftar Pustaka}

\section{Publikasi Resmi Pemerintah}

Departemen Pertahanan AS, 1971a. The Pentagon Papers: the Defense Department History of United States Decision Making on Vietnam, volume I. Boston: Beacon Press.

Departemen Pertahanan AS, 1971b. The Pentagon Papers: the Defense Department History of United States Decision Making on Vietnam, volume II. Boston: Beacon Press.

Departemen Pertahanan AS, 1971c. The Pentagon Papers: the Defense Department History of United States Decision Making on Vietnam, volume III. Boston: Beacon Press.

Departemen Pertahanan AS, 1971d. The Pentagon Papers: the Defense Department History of United States Decision Making on Vietnam, volume IV. Boston: Beacon Press.

\section{Buku atau Artikel dalam Buku}

Ang Cheng Guan, 2013. "The Cold War in Southeast Asia", dalam R. H. Immerman dan Petra Goedde (eds.), The Oxford Handbook of the Cold War. Oxford: Oxford University Press.

Brock, Lothar, 2006. "Triangulating War: the Use of Force by Democracies as a Variant of Democratic Peace", dalam Anna Geis et al. (eds.), Democratic Wars: Looking at the Dark Side of Democratic Peace. New York: Palgrave Macmillan.

Chaliand, Gerard, 1972. "Ideology and Society: The Pentagon papers and South Vietnam", dalam Noam Chomsky dan Howard Zinn (eds.), The Pentagon Papers: Critical Essays, volume V. Boston: Beacon Press.

Daase, Christopher, 2006. "Democratic Peace-Democratic War: Three Reasons Why Democracyes are War-Prone", dalam Anna Geis et al. (eds.), Democratic Wars: Looking at the Dark Side of Democratic Peace. New York: Palgrave Macmillan.

Dockrill, Michael L. dan Michael F. Hopkins, 2006. The Cold War, 1945-1991, edisi kedua. New York: Palgrave Macmillan. 
Modelski, George, 1987. Long Cycles in World Politics. London: Palgrave Macmillan.

Mumford, Andrew, 2013. Proxy Warfare. Cambridge: Polity Press.

Rengger, Nicholas, 2006. "On Democratic War Theory”, dalam Anna Geis et al. (eds.), Democratic Wars: Looking at the Dark Side of Democratic Peace. New York: Palgrave Macmillan.

Swift, John, 2003. The Palgrave Concise Historical Atlas of the Cold War. New York: Palgrave Macmillan.

Turnbull, C. M., 2008. "Regionalism and Nationalism", dalam NicholasTarling (ed.), The Cambridge History of Southeast Asia, volume dua. Cambridge: Cambridge University Press, hlm. 585-642.

Von Hippel, Karin, 2004. "Introduction: Dangerous Hubris", dalam Democracy by Force: US Military Intervention in the PostCold War World. Cambridge: Cambridge University Press.

Weatherbee, D. E., 2009. "The Cold War in Southeast Asia", dalam International Relations in Southeast Asia: the Struggle for Autonomy, edisi kedua. Lanham: Rowman and Littlefield Publishers, hlm. 63-90.

\section{Artikel Jurnal}

Chua, Beng-Huat, 2001. "Notes on the Cold War in Southeast Asia", Inter-Asia Cultural Studies, 2 (3): 481-485.

Duncanson, Dennis J., 1967. "Pacification and Democracy in South Vietnam”, The World Today, 23 (10): 410-418.

Doyle, Michael W., 2005. "Three Pillars of the Liberal Peace", American Political Science Review, 99 (3): 463-466.

Fearon, James D., 1995. "Rationalist Explanation to War", International Organization, 49 (3): 379-414.

Hack, K. dan G. Wade, 2009. "The Origins of the Southeast Asian Cold War", Journal of Southeast Asian Studies, 40 (3): 441448. 
Jervis, Robert, 1988. "War and Misperception", The Journal of Interdisciplinary History, 18 (4): 675-700.

Lockhart, Greg, 1993. "Vietnam: Democracy and Democratisation", Asian Studies Review, 17 (1): 135-142.

Mansfield, Edward D. dan Jack Snyder, 1995. "Democratization and War", Foreign Affairs, 74 (3): 79-97.

Rosato, Sebastian, 2003. "The Flawed Logic of Democratic Peace Theory", American Political Science Review, 97 (4): 585-602.

Tsutsui, Yoichi, 2004. "The Lessons of German Reunification and Its Implications for the Reunification of Korea”, 27: 146-171.

Wade, G., 2009. “The Beginnings of a 'Cold War' in Southeast Asia: British and Australian Perceptions", Journal of Southeast Asian Studies, 40 (3): 543-565.

Zisser, Eyal, 2018. "Why has Bashar Won the War in Syria", Strategic Assessment, 21 (2).

\section{Laporan Penelitian, Tesis, dan Disertasi}

Kim, Min Jung, 2009. "Becoming One: a Comparative Study of National Unification in Vietnam, Yemen, and Germany", Tesis Master. Washington D.C.: Faculty of the Graduate School of Arts and Sciences of Georgetown University.

Min Shu, 2017. "Southeast Asia and the Cold War", dipresentasikan dalam International Relations of Southeast Asia, 6 November. Tokyo: School of International Liberal Studies Waseda University.

Pugh, Jeff, 2005. "Democratic Peace Theory: a Review and Evaluation", CEMPROC Occasional Paper Series, April. Cumming: Center for Mediation, Peace, and Resolution of Conflict Inrernational. 


\section{Film}

Spielberg, Steven (sutradara), 2017. The Post [film]. Los Angeles: 2oth Century Fox.

\section{Publikasi Daring}

Nystorm, 2019. "The Nystorm Complete World History Map Set", The Nystorm World History Series [online]. Tersedia dalam: https://www.socialstudies.com/c/product. web?nocache@2+s@YlIlvIIoi8a12+record@ TF44098+Title@THE+NYSTROM+COMPLETE+WORLD+ HISTORY+MAP+SET [diakses pada 13 Juni 2019]. 
Keterlibatan Amerika Serikat dalam Perang Vietnam:

Faktor Ideologi, Identitas, dan Idealisme 